\title{
New records of Eugenia brejoensis Mazine (Myrtaceae) and complementary description
}

\author{
Augusto Giaretta ${ }^{1 *}$ and Ariane Luna Peixoto ${ }^{2}$ \\ 1 Instituto de Pesquisas Jardim Botânico do Rio de Janeiro, Escola Nacional de Botânica Tropical, Graduate Program in Botany. Rua Pacheco Leão, \\ 2020. CEP 22460-036. Rio de Janeiro, RJ, Brasil. \\ 2 Instituto de Pesquisas Jardim Botânico do Rio de Janeiro. Rua Pacheco Leão, 915. CEP 22460-030. Rio de Janeiro, RJ, Brasil. \\ * Corresponding autor. E-mail: augustogiaretta@gmail.com
}

\begin{abstract}
Eugenia brejoensis Mazine was previously known only from hinterland highland forests in the Caatinga Domain in Pernambuco, northeastern Brazil. Its occurrence is hereby expanded northwards and southwards, it being now recorded in hinterland highland forests in Paraiba and Alagoas, and in coastal forest in Sergipe and northern Espírito Santo. We also present additional information about phenological stages and complementary description of petals and fruits.
\end{abstract}

DOI: $10.15560 / 10.5 .1176$

The Atlantic Forest is one of the greatest forests in South America, with high rates of endemism and species richness (Myers et al. 2000), comprising, along with the Caatinga Domain, the majority of the Brazilian coast extension. The Northeastern Atlantic Forest, located north of the São Francisco River, presents both ombrophilous and semi-deciduous forest vegetation types (Tabarelli and Santos 2004). The Caatinga Domain is one of the largest semi-arid areas of South America, being limited by the Borborema plateau and suffering limited influence of the moist air mass from the Atlantic Ocean (IBGE 2004). This semi-arid climate presents strong seasonality with low rainfall, some areas with less than $1000 \mathrm{~mm}$ of annual rainfall (Prado 2003). In contrast, some areas in the interior of Caatinga Domain constitute enclaves of highland forests with more than $1200 \mathrm{~mm}$ annual rainfall, surrounded by semi-arid vegetation, called brejos de altitude (Ferraz et al. 1998; Andrade-Lima 1982, 2007). In fact, these areas are associated with high geographical elevations (such as Borborema and Araripe plateau), acting as islands of moist condition, where seasonal semi-deciduous forests are nested (Andrade-Lima 2007). Despite brejos de altitude being located in the Caatinga Domain, in some cases the species composition is more related to the Atlantic Forest than to the surrounding semi-arid vegetation (Tabarelli and Santos 2004). This relationship can be linked to Pleistocene interglacial wet period, which allowed the expansion of areas suitable to the expansion of the Atlantic Rainforest into the current boundaries of the Caatinga Domain. When climate conditions changed again and entered a dry period, the Atlantic forest returned to its original distribution range but some areas still under suitable conditions were retained (Andrade-Lima 1982). Thus, this is the probable reason why brejos de altitude holds a substantial portion of diversity and endemism in Northeastern Brazil and share several species with the Atlantic Forest. This is the case of Eugenia brejoensis Mazine, an endemic species found in the Caatinga Domain, on Pernambuco state (Mazine and Souza 2008) that was after recorded on northern and southern Brazil. Besides this new data about this species distribution, we also present additional information about phenological stages and a description of the fruit and petals, not included in the protologue description due to lack of available material.

Eugenia brejoensis Mazine, Bot. J. Linn. Soc. 158: 776 (2008).

Type: Brazil, Pernambuco, Brejo da Madre de Deus, Mata do Malhada, $08^{\circ} 11^{\prime} 14^{\prime \prime}$ S, $36^{\circ} 24^{\prime} 63^{\prime \prime}$ W, L.M. Nascimento et al. 504, 20.III.2001 (holotypus CEPEC, isotypus CEPEC).

Shrubs to trees, 1-11 m height, bark peeling as sheets of paper. Young twigs, leaves, pedicels, flowers and fruits with puberulous indumentum. Leaves 4.5-10.5 × 2.3-5.5 $\mathrm{cm}$, elliptic or ovate, discolor when dry and in nature; apex acuminate; base acute or obtuse; primary vein plain or adaxially sulcate; secondary veins $10-16$ pairs; petioles 3.5-11 mm length. Axillary raceme, rachis 2-12 mm length, 2-6 flowers; pedicels 2.5-10 mm; calyx 4-lobed, 1.8-3 × 1.4-2.5 mm, suborbiculate or oblong, unequal in size; petals $4,2-3 \times 1.5-2 \mathrm{~mm}$, white, ovate, glabrescent on external face, glabrous on internal face; ovary bilocular with 10-12 ovules per locule. Fruit 5-6 × 6-8 mm, globose and slightly flattened in the extremity, red, then black when mature, sparsely pilose, seeds 1(2) with chartaceous testa, embryo with fused cotyledons and no evident hypocotyl (Figures 1 and 2).

In nature, this species is usually a shrub with hanging leaves that seem to be going through a dehydration process, a useful character to recognize the species in the field. The fruit is sparsely covered with smooth hairs that contrast with the dark mature fruit. This species differ from others by short smooth greyish hair covering leaves, flowers and fruits; leaves discolor when dry and in nature; short axillary racemes; bracteoles with a connate base and persistent on fruits. Plants with flowers were collected from January to July and with fruits from March to October.

Eugenia brejoensis has been considered endemic to northeastern Brazil, known only from hinterland highland forest enclaves, locally called brejo, in the Caatinga Domain on Pernambuco state (Mazine and Souza 2008; Sobral et al. 2014). Hereby its distribution 


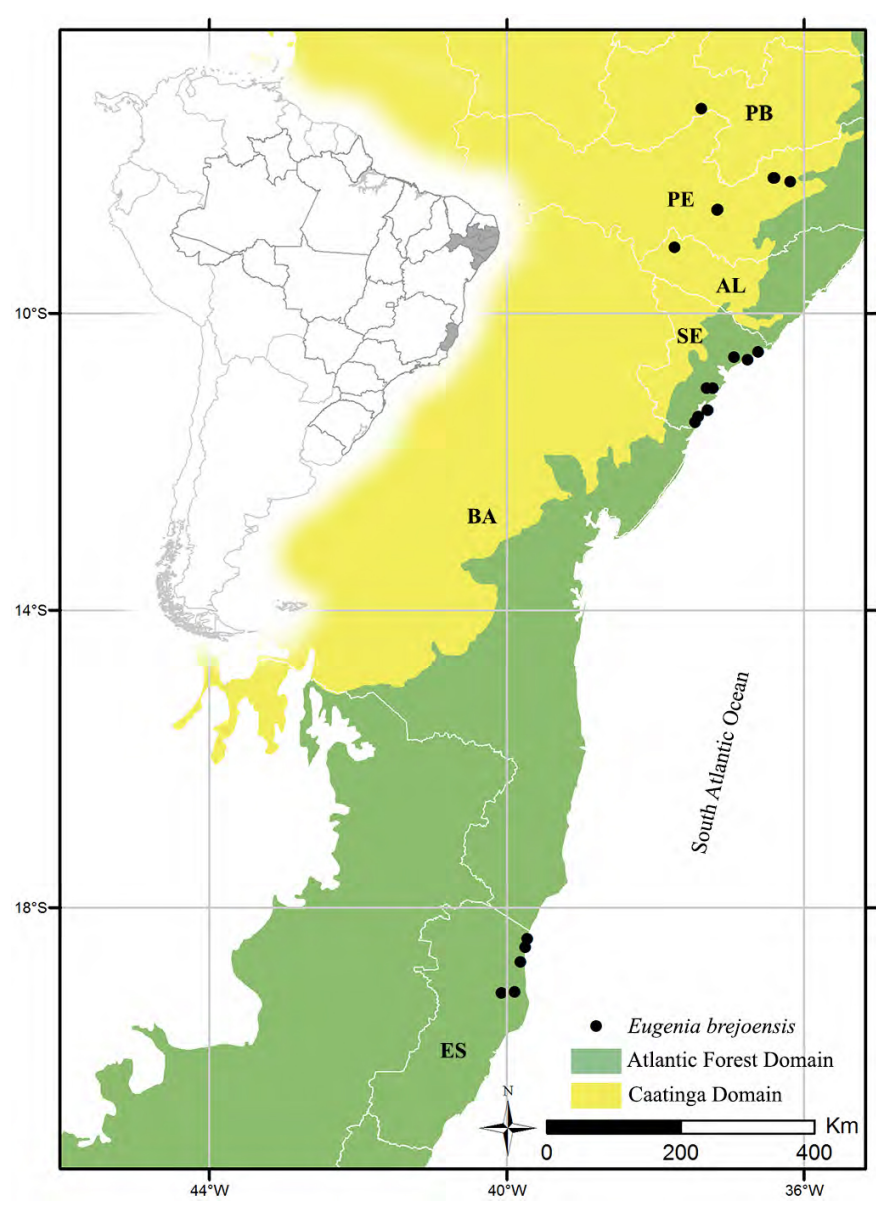

FIGURE 1. Geographical distribution of Eugenia brejoensis Mazine. PB Paraíba; PE - Pernambuco; AL - Alagoas; SE - Sergipe; BA - Bahia; ES - Espírito Santo.

is expanded northwards to the states of Alagoas and Paraíba, where it also occurs in brejos de altitude, and southwards to Sergipe, where it occurs in coastal vegetation on Quaternary or Tertiary plains called restinga and floresta de Tabuleiro, respectively. Still southwards, its geographical distribution is expanded to Espírito Santo state, southeastern Brazil, where it also occurs in floresta de Tabuleiro, characterized as a seasonal semi-deciduous forest with a $1200 \mathrm{~mm}$ rainfall annual mean (Jesus \& Rolim 2005), and both in restinga forest and in close scrub restinga formations, which are non-flooded.

It is not clear if the current distribution of $E$. brejoensis is due to the evolution of historical process of the Atlantic coastal vegetation or to consequences of long distance dispersion or anthropic influence. Biogeography and molecular dating studies are required to elucidate this issue.

Material examined: BRAZIL. Alagoas: Mata Grande, 20.XII.1974, fl., A.D. Andrade Lima 74 (RB). Espírito Santo: Conceição da Barra, Itaúnas, Fazenda Jequitaia, 7.III.2009, fr., A.G. Oliveira \& M.M. Monteiro 477 (RB, VIES); 1.V.2010, fl., A.G. Oliveira et al. 789 (RB, VIES); 11.II.2011, fl., A.G. Olveira \& T.L. Rocha 954 (RB, VIES); Parque Estadual de Itaúnas, Trilha do Buraco do Bicho, 26.I.2012, fr., A. Giaretta \& M. Ribeiro 1214 (RB, VIES); 21.IX.2006, fr., L.F.T. Menezes 1563 (RB, VIES); São Mateus, Bairro Liberdade, 14.IV.2007, fr., A.G. Oliveira \&
M.B. Faria 46 (RB, VIES); 16.I.2008, fl. e fr., A.G. Oliveira et al. 189 (RB, VIES); Aracruz, Reserva Biológica de Comboios, 13.XI.1991, fr., O.J. Pereira et al. 2423 (RB, VIES); 27.VII.1992, fl., O.J. Pereira \& J.M.L. Gomes 3585 (RB, VIES); 28.X.1992, fr., O.J. Pereira et al. 4016 (RB, VIES); Linhares, "nativo", 14.III.2007, fr., L.F.T. Menezes et al. 1626 (VIES). Paraíba: Maturéia, Pico do Jabre, 1.I.2009, fl., M.C.L. Cunha (JPB). Pernambuco: Buíque, estrada Buíque-Catimbau, 10.VI.1995, fl., K. Andrade 124 (isoparatypus RB); Sítio Pititi, sopé da Serra Branca, 23.I.1997, fl., A.P.S. Gomes \& E. Inácio 396 (isoparatypus RB); 3.III.1997, fl., A. Laurênio et al. 427 (isoparatypus RB). Sergipe: Japaratuba, P.A. Ivan Ribeiro, 6.I.1997, fr., M.F. Landim et al. 1129 (ASE); Itaporanga d'Ajuda, Fazenda Trapsa, 15.XII.2008, fl., I.S. Matos et al. 112 (ASE); 17.V.2011, fr., L.A. Gomes \& E. Santos 134 (ASE); Estância, Praia do Abais, 12.III.2012, fl., C.E.B. Proença 4061 (UB); Santa Luzia do Itanhy, RPPN Mata do Castro, 10.IV.2011, fr., L.A. Gomes 118 (ASE).

ACKNowledgements: The authors thank Luciana Dias Thomaz and Rafaela Campostrini Forzza, curators of VIES and RB, respectively, for their kind collaboration; the Sistema Nacional de Pesquisa em Biodiversidade (SISBIOTA-Brazil, CNPq) for financing the project entitled "Rede Integrada em Taxonomia de Plantas e Fungos", to which the present study was linked; the first author thanks the Coordenação de Aperfeiçoamento de Pessoal de Nível Superior (CAPES) for financial support; the second author thanks the Conselho Nacional de Desenvolvimento Científico e Tecnológico (CNPq) for financial support; and we also thank the two anonymous reviewers for their helpful observations about this manuscript.

\section{Literature Cited}

Andrade-Lima, D. 1982. Present day forest refuges in northeastern Brazil; pp. 245-254, in: G.T. Prance (ed.). Biological Diversification in the Tropics. New York: Columbia University Press.

Andrade-Lima, D. 2007. Estudos fitogeográficos de Pernambuco. Anais da Academia Pernambucana de Pesquisas Agronômicas 4: 243-274 (http://ainfo.cnptia.embrapa.br/digital/bitstream/item/34635/1/ AAPCA-V4-Artigo-01.pdf).

Ferraz, E.M.N., M.J.N. Rodal, E.V.S.B. Sampaio and R.C.A. Pereira. 1998. Composição florística em trechos de vegetação de caatinga e brejo de altitude na região do Vale do Pajeú, Pernambuco. Revista Brasileira de Botânica 21(1): 7-15 (doi: 10.1590/S0100-84041998000100002).

IBGE [Instituto Brasileiro de Geografia e Estatística]. 2004. Mapa de biomas do Brasil: Primeira Aproximação. Rio de Janeiro: IBGE.

Jesus, R.M. and S.G. Rolim. 2005. Fitossociologia da Mata Atlântica de Tabuleiro. Boletim Técnico da Sociedade de Investigações Florestais 19: 1-149.

Mazine, F.F. and V.C. Souza. 2008. A new species of Eugenia (Myrtaceae) from north-eastern Brazil. Botanical Journal of the Linnean Society 158(4): 775-777 (doi: 10.1111/j.1095-8339.2008.00921.x).

Myers, N., R.A. Mittermeier, C.G. Mittermeier, G.A.B Fonseca and J. Kent. 2000. Biodiversity hotspots for conservation priorities. Nature 403(6772): 853-858.

Prado, D.E. 2003. As caatingas da América do Sul; pp. 3-74, in: I.R. Leal, M. Tabarelli and J.M.C. da Silva (ed.). Ecologia e Conservação da Caatinga. Recife: Universidade Federal de Pernambuco.

Sobral, M., C. Proença, M. Souza, F. Mazine, E. Lucas. 2014. Myrtaceae, in: Lista de Espécies da Flora do Brasil. Jardim Botânico do Rio de Janeiro, Rio de Janeiro. Accessible at http://reflora.jbrj.gov.br/jabot/ listaBrasil. Captured on 4 September 2014.

Tabarelli, M. and A.M.M. Santos. 2004. Uma breve descrição sobre a história natural dos brejos nordestinos; pp. 99-110, in: K.C. Pôrto, J.J.P. Cabral and M. Tabarelli (org.). Brejos de Altitude em Pernambuco e Paraíba: História Natural, Ecologia e Conservação. Brasília: Ministério do Meio Ambiente. 324 pp.

RECEIVED: June 2013

ACCEPTED: July 2014

PUBLISHED ONLINE: October 2014

EDITORIAL RESPONSIBILITY: Frederico Augusto Guimarães Guilherme 

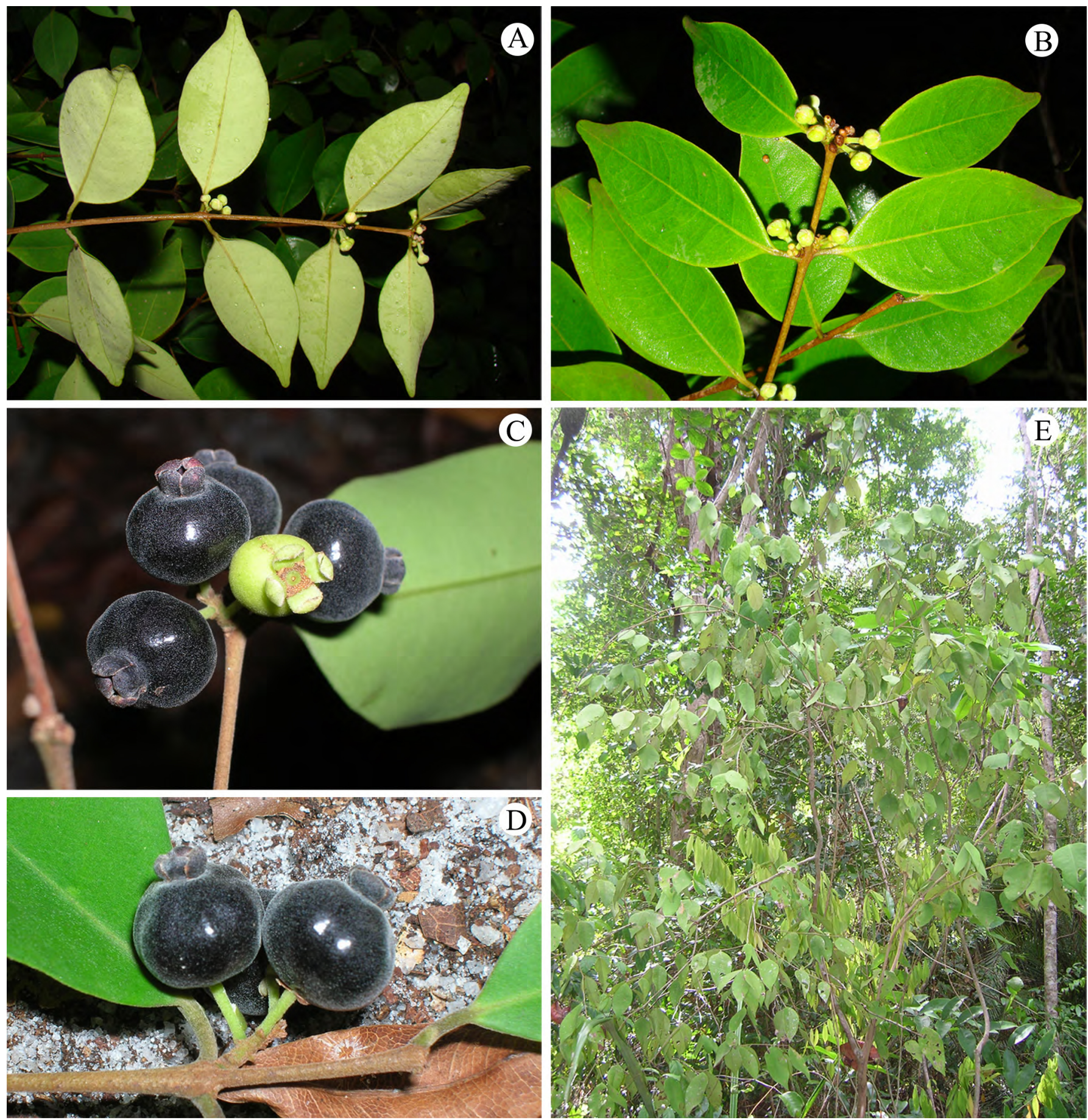

FigURE 2. Eugenia brejoensis Mazine. A, Abaxial surface of leaf; B, Adaxial surface of leaf; C, mature and immature fruit; D, mature fruits with persistent bracteoles at the base; E, habit. (all photos by A. Giaretta from Conceição da Barra, Espírito Santo). 